\title{
GENETIC EVIDENCE OF GENE FLOW FROM INDIANS TO MALAYS
}

\author{
Y.S. TENG* and S.G. TAN** \\ *University of California ICMR, Institute for Medical Research, Kuala Lumpur, Malaysia \\ **Department of Biology, Faculty of Science and Environmental Studies, \\ Universiti Pertanian Malaysia, Serdang, Selangor, Malaysia
}

\begin{abstract}
Summary Indians appeared in Malaysia early in its history. Sustained contacts often resulted in racial admixture. We have analyzed the biochemical genetic markers phosphohexose isomerase (PHI), lactate dehydrogenase (LDH), adenylate kinase (AK), hemoglobin, rhesus blood group and haptoglobin $(\mathrm{Hp})$ among Malays (the indigenous people of Peninsula Malaysia) and Indians to provide genetic evidence for racial admixture of these two groups. The occurrence of specific rare variants PHI 3-1, LDH Calcutta- 1 and Madras-1, and $\mathrm{Hb} \mathrm{S}$, as well as the gene frequencies of adenylate kinase and haptoglobin in Malays and Indians confirm the gene flow from Indians to Malays.
\end{abstract}

\section{INTRODUCTION}

Enzyme polymorphisms of common alleles occur in human populations at $25-30 \%$ of the loci (Harris and Hopkinson, 1972); rare variants occur at many loci that code for enzyme structure. Harris et al. (1973), in a study of European populations, found 56 rare alleles in 22 of 43 loci tested. The average heterozygosity per locus is 1.76 per 1,000 . Gene frequencies of polymorphic systems are useful for estimating racial admixture and genetic distances between races based on mathematical formulas like those devised by Bernstein (1931) and Cavalli-Sforza and Bodmer (1971). Rare variants, having geographically uneven distributions, can also be valuable for studies of human migration and racial admixture. For example, Kirk (1975) used the rare variants of SOD, LDH and $P_{M G}$ to demonstrate human migration in various parts of the world.

We have surveyed polymorphic and rare variant genetic markers, which indicate Indians have enriched the Malay gene pool in Malaysia and Singapore. Historical evidence of close contacts between Malays and the peoples of India support this hypothesis. Some Indian immigrants share with Malays the Islamic religion; therefore, these Indian immigrants would have had little problem integrating them- 
selves into the Malay community, gradually influencing the development of Malay religion and culture. A review of genetic evidence in light of the history of IndianMalay interactions confirms their racial admixture.

\section{Phosphohexose isomerase ( $P H I$ ) 3-I variant}

Electrophoretic variants of red cell phosphohexose isomerase were first reported by Detter et al. (1968). At least nine variants have been found, though the incidence of these variants is usually very low. However, pHI 3-1 has been found in about $1 \%$ of Asiatic Indians in London (Detter et al., 1968) and in New Delhi (Blake et al., 1970); Saha et al. (1976) reported an incidence of PHI 3-1 in 4-5\% of the Muslims and Brahmins in southwest India. In a survey of only 60 Indians in Singapore, Omoto and Blake (1972) found two individuals of the PHI 3-1 phenotype.

In a survey of 579 Malays in Kuala Lumpur, Lie-Injo and Welch (1972) detected one individual with PHI 3-1 while Omoto and Blake (1972) found two PHI 3-1 individuals among 430 Malays living in Singapore. No PHI 3-1 variant was found in a combined sample of 838 Chinese tested in Malaysia and Singapore (Lie-Injo and Welch, 1972; Omoto and Blake, 1972). Therefore, the few PHI 3-1 phenotypes found in Malays may have originated from intermarriage with Indians, given the high incidence of PHI 3-1 among south Indians who as merchant traders had contact with Peninsular Malaysia as early as the fourth and fifth centuries A.D. Fragmentary inscriptions on stone written in Indian characters found in the southern Kedah and Province Wellesley regions of the Malay Peninsula (Arasaratnam, 1970) attest to these early contacts.

\section{Lactate dehydrogenase (LDH) Calcutta-1 and Madras-1}

Variants of $\mathrm{LDH}$ are reported only sporadically in most populations. Among Caucasians, only seven persons had A variants and one person a B variant in over 4,000 randomly sampled individuals (Vesell, 1965; Mourant et al., 1968). Das et al. (1970) first reported Calcutta-1 (Cal-1), an LDH variant at the A locus. Later it was discovered in $1-4 \%$ of the population of India (Das et al., 1970; Blake et al., 1970; Ananthakrishnan et al., 1970). Madras-1, an LDH variant at the B locus has been found only in Madras city. In a survey of 696 Tamil Hindus in Madras, Das et al. (1970) found two individuals with the Madras-1 variant. The Indians in Malaysia have both LDH variants. In a survey of 1,171 Indians in Kuala Lumpur, Lie-Injo et al. (1973) found 12 individuals with the Cal-1 and five with the Madras-1 variant, giving a combined frequency of about $1.5 \%$; among 1,026 Malays of the same survey, they detected two individuals with the Cal-1 and one with the Madras-1 variant. In a study of 259 Malays in Singapore, Blake et al. (1973) found one LDH variant which was indistinguishable from Cal-1; however, in a screening of over 1,000 Chinese from Kuala Lumpur and 264 Bataks from Sumatra, Indonesia, not a single Cal-1 or Madras-1 variant was detected (Lie-Injo et al., 1973, 1974).

Since Calcutta-1 is widespread among the populations of India, but not in other 
populations, it is likely that Indiants transmitted the Cal-1 and the Madras-1 LDH variants found in Malays of Malaysia and Singapore through genetic admixture.

\section{Adenylate kinase $\left(A K^{2}\right)$ allele}

Fildes and Harris first reported the genetic polymorphism of adenylate kinase (1966). Two common alleles, $A K^{1}$ and $A K^{2}$, are found in most populations; Nigerians and American Indians, however, do not have the $A K^{2}$ allele. Only one individual in a combined sample of over 1,000 Chinese had the AK 2-1 phenotype (Shih and Hsia, 1969; Shih et al., 1968; Welch et al., 1971; Blake et al., 1973; Mondovano and Gaensslen, 1975). The frequency of the $A K^{2}$ allele is very low among Orientals. The gene frequencies of $A K^{2}$ for Orientals in Seattle, USA, Japan and Vietnam are 0,0 and $0.3 \%$, respectively (Giblett and Scott, 1969; Omoto and Harada, 1970; Bowman et al., 1971).

In Indians, $A K^{2}$ frequencies range from $8 \%$ in Brahmins in Madras city (Ananthakrishnan and Kirk, 1969) to $12 \%$ in Muslims of southwest India (Saha et al., 1976), In Malaysia, the $A K^{2}$ frequency in Indians is $8.4 \%$ (Welch et al., 1971), slightly lower than that of $9.8 \%$ found among Indians in England (Rapley et al., 1967). Malays in Malaysia (Chan, 1971; Welch et al., 1971) and Singapore (Blake et al., 1973) have an $A K^{2}$ frequency of less than $2 \%$. Since Indians have the highest frequency for the $A K^{2}$ allele, it is conceivable that all or some of the $A K^{2}$ genes in the Malay population of Malaysia and Singapore may derive from racial admixture with Indians.

\section{Hemoglobin $S$}

High frequencies of the sicke-cell gene have been found in tribal populations from various localities in India, but in the caste populations only sporadic instances of sickle-cell anemia occur, probably because of occasional mixture of tribal and caste populations (Saha and Banerjee, 1973). Vella and Hart (1959) reported the first sickle-cell anemia case in a Malaysian Indian in 1959. Lopez (1966) investigated 240 referral cases for abnormal hemoglobin in 1966 and found four Malaysians of Indian ancestry to have $\mathrm{Hb} \mathrm{S/ \beta}$-thalassemia. Lopez and Lie-Injo (1969), in studying 243 patients who had hemolytic anemia, found three patients (all Indians) who had sickle-cell anemia.

In 1974 Ganesan reported four cases of $\mathrm{Hb} \mathrm{S/ \beta}$-thalassemia; three in Indians and one in a Malay boy. Since then a few more cases of the $\mathrm{Hb} \mathrm{S}$ trait have been found in Malays (Ganesan, 1976) but no $\mathrm{Hb} \mathrm{S}$ has been found in Chinese of Malaysia and Singapore (Lopez and Lie-Injo, 1969; Blake et al., 1973). It is plausible that the few $\mathrm{Hb} \mathrm{S}$ genes found in Malays may have been acquired from the Indians.

\section{Red cell antigen. Rhesus negative gene}

The gene frequencies for $\mathrm{Rh}(-) d$ in Indians range from $17.3 \%$ in Calcutta Bengalis (Sen et al., 1959) to $24.5 \%$ in Christian Indians in Bombay (Sanghvi, 1954). 
The $d$ gene is not present in several populations of southern China, notably the Hakka and Taiwanese (Dewey and Mann, 1967), in Indonesian Chinese (Maruna, 1959) or Calcutta Chinese (mainly Cantonese) (Chaudhuri et al., 1967); neither is it found in Indonesians (Sutarman, 1951; Maruna, 1959) nor Javanese (Simmons and Graydon, 1951).

In 437 Malays of Malaysia, Lopez (1971) found two Rh(-) individuals. Durasaimy (cited in Hawkins, 1974) detected $16 \mathrm{Rh}(-)$ in 5,282 persons tested, an incidence of about $0.3 \%$. The $\mathrm{Rh}(-)$ gene in these individuals may have been obtained from the Indians. Interestingly, Mya-Tu et al. (1971) also postulated that the high frequency of $c d e$ in the Burmese population of Mandalay and the Mons of Moulmein had been introduced by the Indians.

\section{Haptoglobin gene frequencies}

The haptoglobin system has been extensively studied in India and throughout the world. Most studies characterize the populations of south India by low frequencies of the $H p^{1}$ allele, ranging from $5.9 \%$ to $16.9 \%$, except in the Todas whose frequency is $35 \%$ (Kirk et al., 1962). The Indians of Malaysia have $H p^{1}$ frequences of $9.2 \%$ and $10.1 \%$ (Steinberg et al., 1961; Kirk et al., 1960), similar to those of the south Indian populations.

The $H p^{1}$ frequencies for Malays and Indonesians are almost identical, about $30 \%$ in both populations (Kirk et al., 1960; Lie-Injo et al., 1968); the Chinese of Malaysia have $H p^{1}$ frequencies of $27 \%$ and $29 \%$ (Kirk et al., 1960; Steinberg et al., 1961). However, in a survey of Malays from Perlis, a northern state of Peninsular Malaysia, Kirk et al. (1960) found a lower $H p^{1}$ frequency of $20 \%$ for Malays. In the same survey, they found Indians in Perlis have a $H p^{1}$ frequency of about $9 \%$. Thais show an $H p^{1}$ frequency of about $24 \%$ (Kirk and Lai, 1962; Blackwell and Thephusdin, 1963).

Since the beginning of the eithteenth century, Indian Muslims from the Coromandel Coast of India, known as Chulias in Malaysia, settled in Kedah and later on Penang Island and in Perlis. South Indian Muslims, famed for their skill as merchants, gained admittance into Malay kampongs (villages) and established businesses because they shared the Islamic religion with the Malays. By the end of the nineteenth century, the Malay community had absorbed the Indian Muslim settlers, though they still constituted a separate group called Jawi Pekan (Arasaratnam, 1970). The low $H p^{1}$ gene frequency of Malays from Perlis State, which differs significantly from that of the Malay populations in other parts of the country, very likely resulted from Malay-Indian intermarriage, because the Thais, the only other population with whom northern Malays are known to intermarry have an $H p^{1}$ frequency of about $24^{\%} \%$. 


\section{DISCUSSION}

The Indians made their appearance and influence felt in Malaysia early in its history. Indian Muslim merchants played a role in the politics of the Malacca Sultanate (1403-1511) and furthered its development and prosperity. There is evidence that Tamil Muslim families from the Coromandel Coast occupied high positions at the court, intermarried with the royal family and influenced political events. Indian trade with Malacca expanded considerably from the fifteenth century onward; the close commercial and political connections with Malacca resulted in the founding of an Indian settlement there. The Tamil Muslim element was strengthened by continuous immigration from the Coromandel Coast (Arasaratnam, 1970).

Later other Indians settled further to the north in Kedah. There the early contacts between Indians and Malays did not bring about large scale Indian immigration but instead transmitted the Indian language, culture and religion to the Malays. Intermarriage and integration of the immigrant Indians into the Malay community was common.

Around 1840, a large scale Indian migration to and settlement on the Malay Peninsula started with the recruitment of Indian laborers to the Straits settlements for work on the sugar and coffee plantations. The Tamil speaking areas of India supplied most of Malaysia's labor needs because Malaysian recruiters were permitted to secure workers in Madras state. In 1870, the Indian population in Malaysia was about 30,000 ; by 1901, it had quadrupled. Most Indians lived in Perak, Selangor, and Negri Sembilan. Indians immigrated in increasing numbers because of the tremendous demand for laborers on the rubber and, later, the oil palm plantations. Today, the Indians of Peninsular Malaysia number $10,385,000$, $10.6 \%$ of the population.

A great number of biochemical genetic markers are available to illustrate the gene flow from Indians to Malays. We chose only a few to demonstrate marked differences between Indians and Malays. The examples of Calcutta-1 LDH and PHI 3-1 variants are the most convincing as they are both considered Indian traits. The example of $H p^{1}$ frequency we cited is unique because Perlis is a rather small and isolated community and because Indians have characteristically low $H p^{1}$ frequency.

Acknowledgments This work was supported in part by the University of California ICMR grant AI 10051 and by research grant HL 10486, both from the NIH, US Public Health Service, and funds from the Department of Biology, Faculty of Science and Environmental Studies, Universiti Pertanian Malaysia.

We thank Dr. R,L. Kirk, Department of Human Biology, John Curtin School of Medical Research, Canberra, Australia, and Dr. Luan Eng Lie-Injo, G.W. Hooper Foundation, University of California, San Francisco, CA, USA, for reading our manuscript and making comments. 


\section{REFERENCES}

Ananthakrishnan, R., Blake, N.M., Kirk, R.L., and Baxi, A.J. 1970. Further studies on the distribution of genetic variants of lactate dehydrogenase in India. Med. J. Aust. 2: 787-789.

Ananthakrishnan, R. and Kirk, R.L. 1969. The distribution of some serum protein and enzyme group systems in two endogamous groups in S. India. Indian J. Med. Res. 57: 1011-1017.

Arasaratnam, S. 1970. Indians in Malaysia and Singapore. Oxford University Press, London.

Bernstein, F. 1931. Die geographische Verteilung der Blutgruppen und ihre anthropologische Bedeutung. In: Comitato Italiano per lo Studio dei Problemi della Populazione. Instituto Poligrafico dello Stato, Rome.

Blackwell, R.Q. and Thephusdin, C. 1963. Distribution of haptoglobin among Thais. Nature 197: 503.

Blake, N.M., Kirk, R.L., and Baxi, A.J. 1970. The distribution of some enzyme group systems among Marathis and Gujaratis in Bombay. Hum. Hered. 20: 409-416.

Blake, N.M., McDermid, E.M., Kirk, R.L., Ong, Y.W., and Simons, M.J. 1973. The distribution of red cell enzyme groups among Chinese and Malays in Singapore. Singapore Med. J. 14: 2-8.

Bowman, J.E., Carson, P.E., Frischer, H., Powell, R.D., Colwell, E.J., Legters, L.J., Cottingham, A.J., Boone, S.C., and Hiser, W.W. 1971. Hemoglobin and red cell enzyme variation in some populations of the Republic of Vietnam with comments on the malaria hypothesis. Am. J. Phys. Anthropol 34: 313-324.

Cavalli-Sforza, L.L. and Bodmer, W.F. 1971. The Genetics of Human Populations. W.H. Freeman, San Francisco.

Chan, K.L. 1971. Human red cell adenylate kinase polymorphism in West Malaysian populations. Hum. Hered. 21: 173-179.

Chaudhuri, S., Mukherjee, B.N., Ghosh, J., and Roychoudhury, A.K. 1967. Blood groups of the Chinese in Calcutta. Nature 213: 1245.

Das, S.R., Mukherjee, B.N., Das, S.K., Ananthakrishnan, R., Blake, N.M., and Kirk, R.L. 1970. LDH variants in India. Humangenetik 9: 107-109.

Detter, J.C., Ways, P.O., Giblett, E.R., Baughan, M.A., Hopkinson, D.A., Povey, S., and Harris, H. 1968. Inherited variations in human phosphohexose isomerase. Ann. Hum. Genet. 31: 329338.

Dewey, W.J. and Mann, J.D. 1967. Xg blood group frequencies in some further populations. J. Med. Genet. 4: 12-15.

Fildes, R.A. and Harris, H. 1966. Genetically determined variation of adenylate kinase in man. Nature 209: 261-263.

Ganesan, J. 1974. In: Annual Report. Institute for Medical Research, Kuala Lumpur, Malaysia.

Ganesan, J. 1976. In: Annual Report. Institute for Medical Research, Kuala Lumpur, Malaysia.

Giblett, E.R. and Scott, N. 1969. In: Genetic Markers in Human Blood, E.R. Giblett, ed., Blackwell Scientific Publications, Oxford.

Harris, H. and Hopkinson, D.A. 1972. Average heterozygosity per locus in man: An estimate based on the incidence of enzyme polymorphisms. Ann. Hum. Genet. 36: 9-20.

Harris, H., Hopkinson, D.A., and Robson, E.B. 1973. The incidence of rare alleles determining electrophoretic variants: Data on 43 enzyme loci in man. Ann. Hum. Genet. 37: 237-253.

Hawkins, B.R. 1974. The distribution of blood genetic markers in the Malay populations of the Malay Peninsula. Singapore Med. J. 15: 118-127.

Kirk, R.L. 1975. Isozyme variants as markers of population movement in man. In: Isozymes IV. Genetics and Evolution, C.L. Markert, ed., Academic Press, New York.

Kirk, R.L. and Lai, L.Y.C. 1962. The distribution of haptoglobin and transferrin groups in South and Southeast Asia. Acta Gener. Stat. Med. 11: 97-105. 
Kirk, R.L., Lai, L.Y.C., Mahmood, S., and Singh, R.B. 1960. Haptoglobin types in South-East Asia. Nature 185: $185-186$.

Kirk, R.L., Lai, L.Y.C., Vos, G.H., Wickremasinghe, R.L., and Perera, D.J.B. 1962. The blood and serum groups of selected populations in South India and Ceylon. Am. J. Phys. Anthropol. 20: $485-497$.

Lie-Injo, L.E., Kosasih, E.N., and Tann, G. 1974. Variation of several erythrocyte enzymes and serum proteins of Indonesians from North Sumatra. Humangenetik 22: 331-334.

Lie-Injo, L.E., Lopez, C.G., and Ganesan, J. 1973. Lactic dehydrogenase variants in different racial groups in Malaysia. Hum. Hered. 23: 487-491.

Lie-Injo, L.E., Poey-Oey, H.G., and Mossberger, R.J. 1968. Haptoglobins, transferrins and hemoglobin $\mathbf{B}_{2}$ in Indonesians. Am. J. Hum. Genet. 20: 470-473.

Lie-Injo, L.E. and Welch, Q.B. 1972. Electrophoretic variants of 6-phosphogluconate dehydrogenase (6PGD) and phosphohexose isomerase (PHI) in different racial groups in Malaysia. Hum. Hered. 22: 338-343.

Lopez, C.G. 1966. In: Annual Report. Institute for Medical Research, Kuala Lumpur, Malaysia.

Lopez, C.G. 1971. In: Annual Report. Institute for Medical Research, Kuala Lumpur, Malaysia.

Lopez, C.G. and Lie-Injo, L.E. 1969. Hereditary haemolytic anaemias in West Malaysia. Med.J. Malaya 24: 101-106.

Maruna, R.F.L. 1959. Blutgruppen- und Rhesusfaktoren-Häufigkeit bei Indonesiern. Blut 5: 41-42.

Mourant, A.E., Beckman, L., Beckman, G., Nilsson, L.O., and Tills, D. 1968. Erythrocyte lactic dehydrogenase variants in the Icelandic and Swedish populations. Acta Genet. 18: 553-555.

Mondovano, J.A. and Gaensslen, R.E. 1975. Distribution of adenylate kinase and phosphoglucomutase isoenzyme in the population of the city of New York. Hum. Hered. 25: 488-492.

Mya-Tu, M., May-May-Yi, and Thin-Thin-Hliang. 1971. Blood groups of the Burmese population. Hum. Hered. 21 : $420-430$.

Omoto, K. and Blake, N.M. 1972. Distribution of genetic variants of erythrocyte phosphoglycerate kinase (PGK) and phosphohexose isomerase (PHI) among some population groups in south-east Asia and Oceania. Ann. Hum. Genet. 36: 61-67.

Omoto, K. and Harada, S. 1970. Frequencies of polymorphic types of four red cell enzymes in a central Japanese population. Jap. J. Human Genet. 14: 298-305.

Rapley, S., Robson, E.B., Harris, H., and Smith, S.M. 1967. Data on the incidence, segregation and linkage relations of the adenylate kinase (AK) polymorphism. Ann. Hum. Genet. 31: 237-242.

Saha, N. and Banerjee, B. 1973. Haemoglobinopathies in the Indian subcontinent. Acta Genet. Med. Gemellol. 22: 117-138.

Saha, N., Kirk, R.L., Shanbhag, S., Joshi, S.R., and Bhatia, H.M. 1976. Population genetic studies in Kerala and the Nilgiris (south west India). Hum. Hered. 26: 175-197.

Sanghvi, L.D. 1954. Genetic diversity in the people of western India. Eugen. Q. 1: 235-239.

Sen, N.N., Mukherjee, C.L., and Aikat, B.K. 1959. Incidence of ABO and Rh(D) blood group amongst Bengalees. J. Indian Med. Assoc. 33: 210-213.

Simmons, R.T. and Graydon, J.J. 1951. A comparison of the blood groups, subgroups, M-N and $\mathrm{Rh}$ types found in Java with those found in other parts of Indonesia, together with a summary of the evidence for north-south gradients in the values for the blood genes $q, m$, and $R^{1}$. Med. J. Aust. 1: 173-179.

Shih, L.-Y. and Hsia, D.Y.-Y. 1969. The distribution of genetic polymorphisms among Chinese in Taiwan. Hum. Hered. 19: 227-233.

Shih, L.-Y., Hsia, D.Y.-Y., Bowman, J.E., Shih, S.-C., and Shih, P.-L. 1968. The electrophoretic phenotypes of red cell 6-phosphogluconate dehydrogenase and adenylate kinase in Chinese populations. Am. J. Hum. Genet. 20: 474-477. 
Steinberg, A.G., Lai, L.Y.C., Vos, G.H., Singh, R.B., and Lim, T.W. 1961. Grenetic and population studies of the blood types and serum factors among Indians and Chinese from Malaya. Am. J. Hum. Genet. 13: 355-371.

Sutarman 1951. Indonesia Red Cross Society Transfusion Service (a review). Stencilled, Djakarta.

Vella, F. and Hart, P.L.V. 1959. Sickle cell anemia in an Indian family in Malaya. Med. J. Malaya 14: $144-150$.

Vesell, E.S. 1965. Genetic control of isozyme patterns in human tissues. In: Progress in Medical Genetics. Vol. 4, A.G. Steinberg and A.G. Bearn, eds., Grune and Stratton, New York, pp. 128-175.

Welch, Q.B., Lie-Injo, L.E., and Bolton, J.M. 1971. Adenylate kinase and malate dehydrogenase in four Malaysian racial groups. Humangenetik 14: 61-63.

Please send reprint requests to: Dr. Y.S. Teng, c/o Editor, G.W. Hooper Foundation, 1699 HSW, University of California, San Francisco, CA 94143, U.S.A. 